ROCZNIKI TEOLOGICZNE

Tom LXVI, zeszyt 3 - 2019

DOI: http://dx.do.org/10.18290/rt.2019.66.3-8

BP JÓZEF WRÓBEL SCJ

\title{
ETYCZNY WYMIAR RYZYKA W SPORCIE
}

\section{THE ETHICAL DIMENSION OF RISK IN SPORT}

\begin{abstract}
A b s t r a c t. The author discusses the problem of the ethical dimension of risk that accompanies most of sports disciplines. Their practicing only exceptionally creates serious moral problems. As a rule, they become a means for human physical and spiritual health. Practicing extreme sports and high-risk sports can serve the spiritual and moral development of man. However, it must meet the requirements of general and specialist security and must be accompanied by readiness to resign from further climbing, when the real threat exceeds the prudently assessed climber's capabilities.
\end{abstract}

Key words: alpinism; himalaism; risk; sport; moral theology.

Nie istnieje jedna, powszechnie przyjmowana definicja sportu. Różnice występujące w jego określeniach wyrażają się w partykularnych akcentach stawianych przez autorów poszczególnych opracowań, ale swoje źródło mają także w specyfice poszczególnych dyscyplin. Niektóre z nich mają postać czynnego odpoczynku bądź zabawy o charakterze indywidualnym lub grupowym, a więc w pewnym stopniu są ćwiczeniem nieużytecznym. Inne wyrażają się w celowej aktywności ruchowej, przeważnie w postaci ćwiczeń służących osiągnięciu jak najlepszej sprawności fizycznej i psychicznej. Większość określeń sportu eksponuje rywalizację w wymiarach intelektualnych, fizycznych (w tym siłowych) lub mieszanych. W definicjach sportu wskazuje się

Bp dr hab. JózEF WRÓBEL SCJ, prof. KUL - kierownik Katedry Bioetyki Teologicznej na Wydziale Teologii KUL; adres do korespondencji: ul. S. Kard. Wyszyńskiego 2, 20-105 Lublin; e-mail: j.wrobel@ diecezja.lublin.pl 
też na rywalizację i osiągnięcie jak najlepszych wyników. Tylko wyjątkowo w sporcie dostrzega się niepewność zwycięstwa oraz wartości służące rozwojowi duchowemu i moralnemu człowieka ${ }^{1}$.

Niezależnie od definicji sportu pojawia się pytanie o jego etyczny wymiar. Uwidacznia się ono zwłaszcza wtedy, kiedy w praktyce sportu uwzględnia się jego aspekt personalistyczny, czyli jego wielowymiarowe znaczenie dla człowieka. Sport może stać się bowiem atrakcyjną szkołą wartości osobowych w wymiarze cielesnym, psychiczno-duchowym i moralnym. Może on też rozwijać wartości społeczne, kiedy pozytywnie kształtuje relacje interpersonalne i doskonali grupowe współdziałanie. $Z$ drugiej strony może się stać praktyką niszczącą człowieka, czy to z powodu specyfiki danej dyscypliny, czy też przekraczania fizycznych i psychicznych możliwości człowieka.

Moralna ocena sportu domaga się więc dostrzeżenia granic jego uprawiania, poza którymi zatraca on właściwe mu znaczenie i rolę. Zatracając właściwy mu sens, stając się wartością samą w sobie, sport przestaje służyć człowiekowi. Wprost przeciwnie, zniewala go, uprzedmiotawia i stwarza poważne zagrożenie dla istotnych dla niego wartości. W powyższym kontekście pojawia się problem ryzyka w sporcie. Towarzyszy ono w mniejszym lub większym stopniu każdej dyscyplinie sportowej. W przypadku sportów ekstremalnych stanowi ono poważny problem etyczny i domaga się pogłębionej refleksji.

\section{PODSTAWY ETYCZNEJ OCENY SPORTU I ZWIAZZANEGO Z NIM RYZYKA}

Etyczny charakter każdej aktywności domaga się uszanowania osobowej godności człowieka i wartości tę godność afirmujących, wśród których fundamentalne miejsce zajmuje życie i zdrowie. One to bowiem tworza podstawę dla osiagnięcia wszystkich innych wartości duchowych i fizycznych, a także stanowią pierwszy warunek spełnienia właściwych każdemu człowiekowi ról społecznych. Stąd też Jan Paweł II pisze: „[Życie] jest rzeczywistością świętą, która zostaje nam powierzona, abyśmy jej strzegli z poczuciem odpowiedzialności i doskonalili ją przez miłość i dar z siebie ofiarowany Bogu i braciom"2.

\footnotetext{
${ }^{1}$ Por. B. Montanari, Sport, w: Nuovo dizionario di teologia morale, red. F. Compagnoni, G. Piana, S. Privitera, Edizioni Paoline, Milano 1990, s. 1279-1285.

2 JAN PAWEŁ II, Encyklika Evangelium vitae, Rzym 1995, nr 2.
} 
Życie człowieka nie jest wolne od różnych form zagrożeń. Niekiedy mają one postać zdarzenia będącego następstwem trudnego do przewidzenia zbiegu okoliczności. Innym razem są one następstwem nieodpowiedzialnego zachowania. Nie brak też przypadków, kiedy są one świadomą i wolną decyzją; są wprost igraniem ze śmiercią $\mathrm{z}$ własnego wyboru.

Takie formy ryzyka towarzyszą również praktykowaniu dyscyplin sportowych. Najczęściej pojawiające się tutaj niebezpieczeństwa dają się jednak zminimalizować lub wyeliminować przez asekurację, odpowiednie przygotowanie lub korzystanie z właściwego sprzętu. Stąd też moralna ocena większości dyscyplin rzadko budzi poważne zastrzeżenia. W przypadku sportów dużego ryzyka i sportów ekstremalnych ta ocena staje się jednak poważnym wyzwaniem moralnym i zakłada ona wszechstronną analizę warunków towarzyszących uprawianiu danej dyscypliny.

Ryzyko w sporcie nie zawsze jest związane z nieszczęśliwym zbiegiem okoliczności. Niekiedy jest ono nierozłącznie wpisane w naturę danej dyscypliny. Kiedy indziej sam człowiek stwarza zagrożenia poprzez brutalizację sportu, stosowanie dopingu, nieprzestrzeganie zasad fair play, czy też przez brak poszanowania godności osobowej przeciwnika i brak poczucia współodpowiedzialności za jego zdrowie i życie. Do postaw zwiększających zagrożenia należy też zaliczyć ideologizację sportu, ideologizację sukcesu, komercjalizację, fanatyzm sportowy, zniewolenie sportem, kiedy to dana dyscyplina staje się dla sportowca wprost bożkiem i swoistą namiastką religii. Postawy te, całkowicie pochłaniając człowieka, mogą doprowadzić do swoistego zahipnotyzowania samozachowawczego instynktu, w wyniku czego człowiek pozbawia się możliwości obiektywnej oceny grożących mu niebezpieczeństw, czy też dostrzeżenia bezpiecznych granic swoich naturalnych możliwości.

Ocena moralna uprawiania danej dyscypliny sportu nie zawsze jest łatwa. Zgodnie $\mathrm{z}$ wcześniejszymi uwagami w wymiarze podmiotowym musi być ona rozpatrywana $\mathrm{z}$ perspektywy godności osobowej człowieka oraz z punktu widzenia odpowiedzialności za życie i zdrowie. Nie do pominięcia jest też miejsce danej dyscypliny w życiu osobistym sportowca, zwłaszcza w przypadku, kiedy staje się ona celem samym w sobie i zostaje postawiona na szczycie osobistej hierarchii wartości, spychając na dalszy plan wartości nieodzowne dla życia osobistego, rodzinnego i społecznego. Najtrudniejsze do oceny w powyższym wymiarze są aspekty tworzące subiektywne podłoże uprawiania danej dyscypliny. Chodzi tutaj zwłaszcza o ewaluację psychofizycznych uwarunkowań, fizycznej wytrzymałości, naturalnych uzdolnień, profesjonalnego przygotowania i umiejętności posługiwania się profesjonalnym sprzętem. 
W wymiarze przedmiotowym pomocą dla oceny trudniejszych przypadków mogą być okoliczności nieszczęśliwych wypadków, ich statystyka oraz ich przyczyny, zwłaszcza w relacji do przygotowania sportowców i ich uznanego profesjonalizmu.

W końcu w ocenie moralnej uprawiania dyscyplin sportowych może być niezmiennie stosowana w nauczaniu katolickiej etyki i teologii moralnej $z a$ sada czynu o podwójnym skutku ${ }^{3}$. Zgodnie $\mathrm{z}$ tą zasadą w punkcie wyjścia jej aplikacji (jako podstawowy warunek) jest stwierdzenie, że dana dyscyplina sportowa dla obiektywnych racji jest sama w sobie moralnie dobra lub przynajmniej obojętna. Z kolei negatywne konsekwencje, będące pochodnymi ryzyka, moga być traktowane jako skutek uboczny, a więc niezamierzony i niechciany, nawet jeżeli są możliwe do przewidzenia. Muszą jednak istnieć proporcjonalne racje uzasadniające podjęcie tego ryzyka. Racje te muszą być tym poważniejsze, im ryzyko $\mathrm{w}$ większym stopniu przynależy do natury danej dyscypliny, im większe jest prawdopodobieństwo jego wystąpienia i im groźniejsze są jego skutki.

\section{DYSCYPLINY SPORTOWE ZMINIMALIZOWANEGO RYZYKA}

Zgodnie ze wstępnymi uwagami najprostsza postać sportu ma charakter relaksacyjnych ćwiczeń lub zabawy służącej odpoczynkowi i regeneracji sił psychofizycznych. Jest on formą czynnej troski o zdrowie fizyczne, duchowe i zdrowe relacje społeczne ${ }^{4}$. Praktyka takiego sportu jest wolna od profesjonalnych ćwiczeń, rywalizacji i treningów. W pełni zasługuje na uznanie, a w pewnych wymiarach jest także moralnym obowiązkiem, zwłaszcza jeżeli jest on zupełnie wolny od ryzyka. Tę formę sportu pozytywnie ocenia Sobór Watykański II. Mówiąc o „wychowaniu do pełnej kultury ludzkiej” wskazuje na zagospodarowanie wolnego czasu w postaci „ćwiczeń i pokazów sportowych, które [...] przyczyniają się do utrzymywania równowagi ducha, jak

\footnotetext{
${ }^{3}$ Por. E. SchockenhofF, Ethik des Lebens. Grundlagen und neue Herausforderungen, Verlag Herder, Freiburg im Br. 2013², s. 276-278; K.-H. PeschKE, Christliche Ethik. Grundlegungen der Moraltheologie, Paulinus Verlag, Trier 1997, s. 299-309; A. GÜNTHÖR, Chiamata e risposta. Una nuova teologia morale, t. 1: Morale generale, Edizioni Paoline, Roma $1979^{3}$, s. 530-534.

${ }^{4}$ Por. G. PERICO, Sport, w: Dizionario enciclopedico di teologia morale, red. L. Rossi, A. Valsecchi, Edizioni Paoline, Roma $1976^{4}$, s. 1055.
} 
i do braterskich stosunków między ludźmi wszelkiego stanu, narodowości i różnych ras"5.

Bardziej wymagający jest sport amatorski. Jego znaczenie zostaje ubogacone o współzawodnictwo indywidualne lub zespołowe. Stąd jego uprawianie $\mathrm{z}$ reguły wiąże się z metodycznym, systematycznym i zorganizowanym przygotowaniem mającym na celu nabycie odpowiednich technik i osiągnięcie zdolności do profesjonalnych występów ${ }^{6}$. Zasadniczo z praktyką sportu amatorskiego nie wiążą się poważne zagrożenia dla zdrowia i życia. Niemniej i w przypadku tego typu rozgrywek nie można wykluczyć akcydentalnych wypadków. Treningi, ćwiczenia i zawody moga prowadzić do mniej lub bardziej poważnych kontuzji. Tym niebezpieczeństwom mogą jednak zaradzić roztropne zachowania, nadzór ze strony doświadczonego trenera oraz opieka lekarza-specjalisty. Mając na uwadze indywidualne i wspólnotowe znaczenie takich form rywalizacji, możliwe ryzyko zasadniczo nie podważa ich moralnej wartości. Zdarzające się wypadki i kontuzje mają - jak już podkreślono charakter przypadkowy i z reguły nie są one większe od zagrożeń, jakie towarzyszą człowiekowi prowadzącemu aktywne życie.

Poważne wyzwania moralne zaczynają się pojawiać w kontekście praktyki sportu zawodowego. Chociaż jego uprawianiu przeważnie towarzyszy zamiłowanie i charyzma, to do jego istoty należy świadczenie usług i kontrakt finansowy $\mathrm{z}$ określonym stowarzyszeniem sportowym. Z reguły otrzymywane wynagrodzenie nie jest jednakowe dla wszystkich sportowców. Jego wysokość zależy od sportowych osiągnięć, a więc od zwycięstw, od zdobytych medali, od uzyskanych punktów (np. strzelonych bramek). Honorarium dodatkowo motywuje jego zaangażowanie i staje się silnym bodźcem do zwiększenia wysiłku i maksymalnego wykorzystania własnych możliwości. Stąd znacznie wzrasta niebezpieczeństwo wypadku, kontuzji, kalectwa czy przesilenia organizmu kończącego się utratą zdrowia, a nawet śmiercią. Innymi słowy, prawdopodobieństwo wystąpienia nieszczęśliwego wypadku wzrasta proporcjonalnie do wyznaczanych sobie coraz ambitniejszych celów. Tylko w przypadku niektórych sportów ryzyko to jest w pewnym stopniu minimalizowane przez obecność wysokiej klasy trenerów, profesjonalnej opieki lekarskiej, a także przemyślane formułowanie reguł gry chroniących sportowców przed nieszczę-

\footnotetext{
${ }^{5}$ SOBÓR WATYKAŃSKI II, Konstytucja duszpasterska o Kościele w świecie współczesnym Gaudium et spes, Rzym 1965, nr 61; także TENŻE Deklaracja o wychowaniu chrześcijańskim Gravissimum educationis, Rzym 1965, nr 4.

${ }^{6}$ Por. G. Perico, Sport, s. 1055.
} 
śliwymi wypadkami i kontuzjami, a tym samym instytucje, które reprezentują, przed finansowymi stratami.

\section{SPORTY ZWIĘKSZONEGO I DUŻEGO RYZYKA}

Sporty rekreacyjne i amatorskie stanowią podstawową formę ludycznych aktywności człowieka. Równie bardzo rozpowszechniona jest praktyka sportów wyczynowych, z którymi nierzadko jest związane poważne ryzyko. Na specyfikę takich dyscyplin sportowych wskazują wybrane orzeczenia Trybunału Sprawiedliwości Unii Europejskiej. Chociaż Trybunał ten nie podaje ścisłej definicji sportu wyczynowego, to można ją sformułować w oparciu o partykularne jego wypowiedzi. Sugerują one, że sport wyczynowy jest „nakierowany na rywalizację, gdzie nadrzędnym celem jest osiągnięcie jak najlepszego

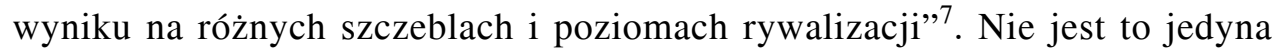
cecha specyficzna tego rodzaju sportu, gdyż praktycznie tło większości dyscyplin sportowych stanowi silna rywalizacja i dążenie do ustanowienia nowych rekordów.

Wartościowej dla refleksji etycznej klasyfikacji sportów, z którymi związane jest poważne ryzyko, dokonują działające w Polsce takie firmy ubezpieczeniowe, jak Warta $^{8}$, Ergo Hestia ${ }^{9}$ i Allianz Direct ${ }^{10}$. Omawiając warunki

${ }^{7}$ J. MAJ, Pojecie sportu wyczynowego w prawie Unii Europejskiej, „Prawo Sportowe.pl”, https://prawosportowe.pl/pojecie-sportu-wyczynowego-w-prawie-unii-europejskiej.html(dostęp: 24.09.2018)

${ }^{8}$ Por. Warta, Ogólne Warunki Ubezpieczenia Warta Travel Plus, https://www.warta. pl/documents/10157/916069/Warta_Travel_plus_OWU.pdf(dostęp: 18.09.2018). Firma ta uznaje za „sporty ekstremalne - sporty wysokiego ryzyka - powietrzne, wodne, lądowe, uprawiane celem osiagnięcia maksymalnych wrażeń”. Za sporty ekstremalne uważa ona również udział w wyprawach do miejsc charakteryzujących się ekstremalnymi warunkami klimatycznymi lub przyrodniczymi, np. góry powyżej 5 500m n.p.m., tereny lodowcowe (z wyłączeniem oznakowanych tras narciarskich), dżungla, busz" (rozdz. I, par. 2, p. 21).

${ }^{9}$ Por. Ergo Hestia, Stownik terminów ubezpieczeniowych, https://www.ergohestia.pl/cen trum-wiedzy/slownik-terminow-ubezpieczeniowych/ (dostęp 20.09. 2018). Firma ta wyróżnia tylko „Sporty wysokiego ryzyka”.

${ }^{10}$ Por. Allianz, Ogólne warunki bezpieczeństwa w podróży Globtroter Direct, https://www. allianzdirect.pl/dokumenty-do-pobrania/owu-globtroter-20101029_literxwka_str_3_pkt_56.pdf (dostęp: 18.09.2018). Firma ta uznaje za sporty wyczynowe, sporty zawodowe, czyli ,regularne lub intensywne treningi przy jednoczesnym udziale w zawodach lub imprezach czy obozach kondycyjnych i szkoleniowych w ramach przynależności do klubów sportowych, związków i organizacji sportowych; czerpanie dochodu z uprawianej dyscypliny sportu, a także wykonywanie pracy jako trener lub instruktor sportu (por. par. 4, p. 63). 
asekuracji od zdrowotnych następstw uprawiania niebezpiecznych dyscyplin, wyróżniają (ale nie rozdzielają) one sporty wysokiego ryzyka i sporty ekstremalne. Brak takiego rozróżnienia raczej nie wynika z matematycznego wyrachowania stopnia zagrożeń związanych $\mathrm{z}$ ich uprawianiem, ale $\mathrm{z}$ uproszczonego algorytmu kwalifikacji warunków kontraktów ubezpieczeniowych.

Powyższe sporty wyraźnie rozróżnia niemiecka firma ubezpieczeniowa, specjalizująca się w ubezpieczeniach turystycznych i sportowych, mająca swoją siedzibę w Monachium i posiadająca również oddział w Polsce (w Gdańsku) - ERV (Europäische Reiseversicherung AG) ${ }^{11}$. W zależności od niebezpieczeństw związanych z ich uprawianiem rozróżnia ona „sporty wysokiego ryzyka” i ,sporty ekstremalne”. Sporty wysokiego ryzyka to między innymi „narciarstwo, [...] sporty uprawiane na rzekach górskich [...], wszelkiego rodzaju aktywności uprawiane na wysokości od 2500 m n.p.m. do 4500 m n.p.m., wspinaczka skałkowa i wysokogórska (z wyjątkiem alpinizmu i himalaizmu)" 12 .

Z kolei do sportów ekstremalnych firma ta zalicza ,uczestniczenie w wyprawach lub ekspedycjach do miejsc charakteryzujących się ekstremalnymi warunkami klimatycznymi lub przyrodniczymi (typu: pustynia, busz, dżungla, bieguny oraz tereny lodowcowe i śnieżne wymagające użycia sprzętu asekuracyjnego) oraz uprawianie dyscyplin sportowych wymagających ponadprzeciętnych umiejętności, odwagi i działania w warunkach dużego ryzyka, często zagrożenia życia: [...] alpinizm, himalaizm, wszelkiego rodzaju aktywności uprawiane na wysokości powyżej $4500 \mathrm{~m}$ n.p.m. oraz w trudnych warunkach terenowych lub klimatycznych, $[\ldots]$ skoki narciarskie, $[\ldots]$ kolarstwo górskie [...] motocross, wszelkiego rodzaju ewolucje akrobatyczne"13.

Zaliczenie powyższych dyscyplin do sportów bardzo ryzykownych sugeruje, że jest z nimi związany duży stopień trudności i są one bardzo wymagające. Angażują one znaczny wysiłek fizyczny (nierzadko także psychiczny) i z ich uprawianiem jest związane poważne niebezpieczeństwo groźnego wypadku, a w efekcie poważnej kontuzji - trwałego kalectwa czy nawet śmierci. Zgodnie z wcześniejszymi uwagami sporty te nie zawsze mają charakter osobistego hobby. Niekiedy są one w jakiejś mierze związane $\mathrm{z}$ wykonywa-

\footnotetext{
${ }^{11}$ Europäische Reiseversicherung AG, https://www.erv.pl/ubezpieczenia/kup-online/?gclid= EAIaIQobChMImLrS1oPF3QIVHoGyCh0dzQCcEAAYASAAEg KA7PD_BwE(dostęp: 18.09.2018).

${ }^{12}$ Europäische Reiseversicherung AG, Ogólne Warunki Ubezpieczenia Beztroskie Podróże Nr 10.10.009, https://www.erv.pl/files/193/148/51/10 10007a4.pdf (dostęp: 20.09.2018), § 2: Definicje, p. 52.

${ }^{13}$ Tamże, § 2: Definicje, p. 50.
} 
niem zawodu i stanowią egzystencjalną konieczność. Najczęściej są jednak uprawiane dla osiągnięcia wyjątkowych celów, wykazania się nieprzeciętną sprawnością i odniesienia osobistych lub zespołowych sukcesów. Domagają się one też wysokiego stopnia opanowania technik właściwych dla danej dyscypliny i na tej płaszczyźnie rozgrywa się zazwyczaj właściwa im rywalizacja.

Powyższa specyfika omawianych sportów stanowi też punkt odniesienia dla ich etycznej oceny. Kryterium podstawowe to obiektywna zdolność zawodnika do ich uprawiania. Chodzi tutaj między innymi o sprawdzone możliwości zdrowotne, o odpowiednie warunki fizyczne i psychiczne, o profesjonalne przygotowanie i ewentualnie o dysponowanie odpowiednim sprzętem.

Kolejne kryterium jest pochodną statystyk nieszczęśliwych wypadków i ich przyczyn. Oznacza to, że często zdarzające się w danej dyscyplinie poważne wypadki w miarę dobrze przygotowanym zawodnikom domagają się zaostrzenia etycznych wymagań, a więc i w większym stopniu nakładają moralną odpowiedzialność. Nakładają też one wyższe wymagania moralne wstępne, czyli domagają się poważniejszych racji usprawiedliwiających podjęcie takiego ryzyka. I odwrotnie, wypadki zdarzające się wyjątkowo, w rzadko spotykanych sytuacjach, pozwalają na obniżenie tych wymagań, a więc zmniejszają też odpowiedzialność moralną, a ryzyko może być łatwiej usprawiedliwione.

Pozostaje pytanie, jakie moralnie pozytywne motywacje mogą wchodzić w grę w przypadku uprawiania ryzykownych sportów? Do takich racji można zaliczyć egzystencjalne potrzeby osobiste sportowców i ich obowiązek utrzymania rodziny oraz uczestnictwo w widowiskowych imprezach, w tym imprezach dobroczynnych. W grę mogą wchodzić również poważne obowiązki zawodowe i zadania społeczne służące dobru wspólnemu społeczności, jak przecieranie nowych szlaków komunikacyjnych, przygotowanie szlaków turystycznych, ćwiczenia i nabywanie zdolności związanych z pełnieniem specjalistycznej służby ratunkowej (np. Górskie Ochotnicze Pogotowie Ratunkowe), zawody motorowe (rajdy motocyklowe i samochodowe) służące sprawdzeniu czy też doskonaleniu nowych rozwiązań technicznych i technologicznych stosowanych w pojazdach powszechnego użytku, ćwiczenia (tzw. poligony) właściwe służbom specjalnym czy specjalistycznym służbom wojskowym ${ }^{14}$.

\footnotetext{
14 Por. PAUL VI, Discours aux représentants des forces armées (du Conseil International du Sport Militaire) (29.11.1969), http://w2.vatican.va/content/paul-vi/fr/speeches/1969/novembe r/documents/hf_p-vi_spe_19691129_forze-armate. html (dostęp: 20.01.2019). W przemówieniu tym pap. Paweł VI zaznaczył m.in.: „Już wielokrotnie podkreśliliśmy wielkie zainteresowanie Kościoła tego typu zawodami, w których tyle ludzkich cnót znajduje pole dla praktykowania [...]. Życzymy, aby nasi katoliccy synowie zawsze lśnili odwagą, prawością i duchem miłości, której ich uczy Ewangelia".
} 
Większość z wyliczonych wyżej dyscyplin ekstremalnych posiada cechy charakterystyczne dla sportów znacznego lub dużego ryzyka. Konsekwentnie również ich ocena etyczna będzie oparta na tych samych zasadach. Nie do pominięcia jest fakt, że $\mathrm{z}$ tymi dyscyplinami jest $\mathrm{z}$ reguły związane wyższe ryzyko i konsekwentnie domagają się one stawiania większych wymagań w zakresie bezpieczeństwa. Domagają się też one poważniejszych racji motywujących ich uprawianie.

\section{WSPINACZKA WYSOKOGÓRSKA - HIMALAIZM}

Pośród wyliczonych sportów ekstremalnych odrębną specyfikę posiada wspinaczka na najwyższe szczyty ziemskiego globu przekraczające wysokość 8000 m n.p.m.: 10 szczytów w Himalajach i 4 w Karakorum ${ }^{15}$. Podobne wyzwania, jednak w ograniczonej mierze, towarzyszą zdobywaniu najwyższych szczytów Andów (Aconcagua - 6961 m n.p.m, Ojos del Salado 6893 m n.p.m., Nevado Pissis - 6793 m n.p.m.) i Alp (najwyższy szczyt - Mont Blanc - 4810 m n.p.m.). Do tej grupy górskich szczytów można

Mając na uwadze powyższe przesłanie pap. Pawła VI, warto wyjaśnić, że 18.02.1948 r. w Nicei została założona Międzynarodowa Rada Sportu Wojskowego (CISM, fr. Conseil International du Sport Militaire). Do organizacji tej należą armie 136 państw, w tym Polski (od 1991 r., po rozwiązaniu Układu Warszawskiego). Zgodnie ze statutem celem organizacji jest „przyjaźń poprzez sport”, czyli rozwój przyjaznych relacji między siłami zbrojnymi państw przynależących do CISM i budowanie pokoju między narodami. Organizacja ta preferuje 26 dyscyplin sportu, a wśród nich m.in. biatlon, biegi narciarskie, bieg patrolowy (połączenie biatlonu z biegami narciarskimi), narciarstwo alpejskie, biegi na orientację, specyficzne pięcioboje (Por. Międzynarodowa Rada Sportu Wojskowego ma 70 lat, „Polska Zbrojna”, http://www.polska-zbojna.pl/home/articleshow/26001?t=Miedzynarodowa-Rada-Sportu-Wojskowego-ma-70-lat (dostęp: 20.01.2019)). W opisie sportowych zaangażowań wojsk polskich wyróżnia się sport powszechny i sport wyczynowy, chociaż określenia te nie są tożsame z przedstawionym wcześniej ich rozumieniem. Jednocześnie określa się cel tych dyscyplin sportu: „obowiązkowe zawody sportowe służą głównie kształtowaniu i wyrabianiu sprawności fizycznej, umiejętności sportowych oraz niezbędnych cech żołnierzy. [...] Rozwijanie dyscyplin sportu, które z punktu widzenia potrzeb wojska są uznawane jako przydatne (m.in. strzelectwo, bieg na orientację, pięcioboje wojskowe, sporty walki) z wyjątkiem spadochroniarstwa (spadochronowa reprezentacja Wojska Polskiego od 1 lipca 2002 roku funkcjonuje w ramach struktur utworzonego w 2. Bazie Lotniczej Bydgoszcz Ośrodka Szkolenia Służby Wysokościowo-Ratowniczej Sił Powietrznych) (Ministerstwo Obrony Narodowej. Gala sportu wojskowego, http://arch iwalny.mon.gov. pl/pl/artykul/2792 (dostęp: 20.01.2019)).

${ }^{15}$ Karakorum to łańcuch górski na pograniczu Indii, Pakistanu i Chin. Jest to drugie po Himalajach najwyższe pasmo górskie na Ziemi. 
jeszcze zaliczyć Elbrus (najwyższy szczyt Kaukazu - 5642 m n.p.m.) i Kilimandżaro (najwyższa góra Afryki - 5895 m n.p.m.).

Himalaizm należy bezwzględnie do najbardziej niebezpiecznych dyscyplin sportowych. Za każdym razem są one próbą wytrzymałości fizycznej, odporności psychicznej, panowania nad sobą, odwagi i przezorności. Profesjonalne przygotowanie dalsze, wyśmienita kondycja fizyczna, doświadczenie, trening, opanowanie technik wspinaczki, odpowiedni sprzęt, to wstępne warunki bezpieczeństwa. Nieodzowny profesjonalizm wyraża się w wykluczeniu ryzyka popełnienia fatalnego w skutkach błędu. Raczej wyjątkowo i to tylko na niższych wysokościach istnieje możliwość przyjścia z pomocą himalaistom znajdującym się w niebezpieczeństwie, w stanie wyczerpania fizycznego lub wpadnięcia w pułapkę, z której nie są w stanie wyjść samodzielnie. Akcję ratunkową uniemożliwia bowiem brak wysokogórskich służb ratunkowych, a ponadto wysokość i słaba widoczność uniemożliwiająca przyjście z pomoca helikoptera. Wielkie zagrożenie stanowi też nagłe załamanie pogody bez możliwości wycofania się do jakiegoś schroniska czy obozów założonych w niższych partiach gór.

Jednak źródłem największego niebezpieczeństwa są wspomniane wysokości z panującym na nich niedostatkiem tlenu. Osoby posiadające sprawnie funkcjonujący organizm mogą do pewnego stopnia zminimalizować to zagrożenie poprzez aklimatyzację. Robert Szymczak, polski lekarz, specjalista w zakresie medycyny wysokogórskiej, zdobywca trzech himalajskich ośmiotysięczników i wielu innych szczytów zaliczanych do korony świata, podkreśla, że bez kilkutygodniowej aklimatyzacji przebywanie powyżej $5000-5500 \mathrm{~m}$ n.p.m. prowadzi do wyniszczenia organizmu. Człowiek nie może przemieścić się od razu na wysokość większą niż 2.500 m n.p.m. Różnica wysokości między kolejnymi noclegami nie powinna być większa niż $300 \mathrm{~m}$. Jeżeli pokona się na raz większą wysokość, konieczny jest dodatkowy dzień na dostosowanie się organizmu. Zbyt szybkie przemieszczenie się nawet wysportowanego człowieka na wysokość $7500 \mathrm{~m}$ n.p.m. spowoduje śmierć po kilkunastu minutach. Sama aklimatyzacja (nawet wzmocniona środkami medycznymi, jak Acetazolamid (Diuramid)), nie rozwiązuje problemu niedotlenienia. Na dużych wysokościach również człowiek zaaklimatyzowany szybko traci swoje możliwości fizyczne: na Mont Blanc traci ich około $30 \%$, a na Mount Everest $80 \%{ }^{16}$.

${ }^{16}$ R. SZYMCZYK, MedEverest Mountain Expedition Medicine, http://medev erest.com/ofirmie.html (dostęp: 27.09.2018); także TENŻE MedEverest Mountain Expedition Medicine: Aklimatyzacja, http://medeverest.com/aklimatyzacja.html (dostęp: 27.09.2018). 
Kolejne ograniczenie wynika $\mathrm{z}$ dopuszczalnego czasu przebywania na takich wysokościach. Pozostawanie na wysokości około 5000 m n.p.m. może spowodować zaburzenie funkcji biologicznych, obrzęk mózgu ${ }^{17}$ i płuc, ograniczenie świadomości, strach przed śmiercią paraliżujący racjonalne postępowanie. Wysokość 7500 m n.p.m. jest uznawana za granicę śmierci biologicznej. Powyżej tej wysokości człowiek może przebywać kilka godzin, tylko wyjątkowo kilka dni.

Wysiłek związany z zdobywaniem himalajskich szczytów i towarzyszące mu doświadczenia opisuje Jerzy Kukuczka, polski himalaista, który zdobył koronę Himalajów i Karakorum ${ }^{18}$ : „Opowiadałem, jakiego wysiłku wymagają na dużych wysokościach najprostsze nawet ruchy. Gdy niemal każde dźwignięcie ciała w górę o kilkanaście centymetrów trzeba okupić parominutowym wypoczynkiem, oddechu zaczyna brakować już po wbiciu haka, a samo utrzymanie równowagi bywa ogromnie męczące. [...] Ile sił musiałem dobyć, by przejść ową skalną barierę, wystarczy jedna tylko informacja. Przez cały dzień nieustannej wspinaczki pokonałem dwadzieścia metrów. Sam niezbyt dokładnie zdawałem sobie z tego sprawę, co się ze mną działo, gdy przemierzałem ostatni fragment bariery. Niemal cała piętrzyła się pionowo, a tych kilka końcowych metrów musiało być nawet lekko przewieszonych. Nie pamiętam z nich zupełnie nic. [...] Nic nie widziałem przez czarne plamy migające mi przed oczyma. Jak długo to trwało, nie wiem. Kilka ostatnich ruchów kosztowało mnie tak dużo, że przestałem nawet panować nad fizjologicznymi odruchami. O tym, że spodnie mam mokre od moczu, przekonałem się jednak dopiero za krawędzią - gdy doszedłem do siebie"19.

Powyższy obraz himalaizmu, wyostrzony świadomością śmiertelnych wypadków, rodzi pytanie o jego wymiar etyczny ${ }^{20}$. W punkcie wyjścia warto

\footnotetext{
${ }^{17}$ Obrzęk mózgu jest jednym z najniebezpieczniejszych objawów choroby wysokogórskiej. Obrzęk ten poprzez wytworzenie ciśnienia w czaszce prowadzi do zablokowania centrów regulujących pracę serca i układu oddechowego. W efekcie tego obrzęku człowiek umiera (por. J. KukUCZKa, T. Malanowski, Na szczytach świata, Fundacja Wielki Człowiek, Katowice $2013^{3}$, s. 169).

${ }^{18}$ Jerzy Kukuczka zginął 24.10.1989 r. podczas wejścia na Lhotse przez niezdobytą wówczas południową ścianę.

19 J. KukUCZKa, T. Malanowski, Na szczytach świata, s. 162-163.

${ }^{20}$ Powyższy wymiar refleksji obrazują np. niniejsze zestawienia: w czasie zdobywania ośmiotysięcznika Kanczendzonga zginęło kilkanaście kobiet, zaledwie dwie stanęły na szczycie, a tylko jedna przeżyła; w sezonie 1986 roku na K2 zginęło 13 wspinaczy, w tym 3 Polaków; w 1989 r. zginęło pięciu Polaków uczestniczących w wyprawie na Mount Everest (por. K. PYTLAKowsKa, Piękna himalaistka Kinga Baranowska zdradza swoje tajemnice [wywiad], „Pol ki.pl",https://polki.pl/zycie-gwiazd/newsy,himalaistka-kinga-baranowska-w-vivie-wywiad-z-kin
} 
zauważyć, że do uprawiania himalaizmu nie są w stanie zachęcić płytkie motywacje, pragnienie przeżycia silnych wrażeń, zdobycie sławy, czy też charakterystyczna dla innych sportów rywalizacja (tylko w sensie niewłaściwym można by ją dostrzec w informacjach, kto pierwszy zdobył dany szczyt, z której strony się na niego wspiął, dokonał tego latem czy zimą). Himalaizm jest sportem wysoce elitarnym. Nie wystarczy być odpowiednio przygotowanym, posiadać kondycję fizyczną, odpowiednie kwalifikacje zdrowotne i profesjonalne przygotowanie. Jak już podkreślono, na wspinaczkę w ekstremalnych warunkach może się zdecydować tylko człowiek posiadający odpowiednie dyspozycje osobowościowe i psychiczne. Relacje himalaistów pozwalają stwierdzić, że uprawianie tego sportu przeważnie wypływa z przekonania o wartości doświadczeń duchowych i metafizycznych; z chęci wzniesienia się ponad dotychczas sprawdzone osobiste możliwości; z potrzeby afirmacji swojego człowieczeństwa poprzez silną wolę zdolną zapanować nad słabością i lękiem ${ }^{21}$. W zmaganiach ze sobą w ekstremalnych warunkach życie nabiera nowej wartości i wymiarów, łatwiej je odnieść do Boga i doświadczyć Jego piękna przez intensywne obcowanie z potęgą natury, ciszą i samotnością.

Na taką motywację wskazują sami himalaiści. Podkreślają oni, że w wspinaczce wysokogórskiej bynajmniej nie chodzi o zaliczanie kolejnych szczytów, ale o wzbogacenie swojego człowieczeństwa. Kinga Baranowska, polska himalaistka, zdobywczyni dziewięciu ośmiotysięczników, opowiada, dlaczego góry ją tak przyciągają: „Pamiętam, gdy po raz pierwszy się pojawiłam [w górach], kompletnie oszalałam. Moment, w którym stanęłam po raz pierwszy nad chmurami, był mistyczny. Wbiegałam na szczyty jak dzikus [...]. I nie chodziło o rywalizację. Chciałam zobaczyć wszystko naraz. [...] [Do tego doszło] delektowanie się [górami]. [Tego sportu] nie uprawia się dla popularności. [...] Zdarzało mi się zawracać 100 metrów od szczytu. Istnieje taka linia, której nie przekraczam, gdyż stanowi próg ryzyka dla mnie nieakceptowalny. Nie na darmo mówi się, że góry uczą pokory [...]. Należy też

ga-baranowska-w-vivie,10032989,artykul.html (dostęp: 20.09.2018); Etyka we wspótczesnym alpinizmie - Szczyt Gliwicki 1987 (cz. 1), „Wspinanie.pl”, https://wspinanie.pl/2013/10/etykawe-wspolczesnym-alpinizmie-szczyt-gliwicki-1987-cz-1/ (dostęp: 20.09.2018).

${ }^{21}$ J. Kukuczka wskazuje na wielkie znaczenie lęku: „[strach] jest największym wrogiem alpinisty [...], jest naturalnym stymulatorem zachowania w niebezpiecznych sytuacjach. Ktoś, kto go nie odczuwa, nie powinien się wspinać. Jest skazany na rychłą śmierć” (J. KUKUCZKA, T. MalanowsKI, Na szczytach świata, s. 87). 
wiedzieć, kiedy zawrócić. Ale by to wiedzieć, trzeba poznać samą siebie" ${ }^{22}$. Innym razem Kinga Baranowska stwierdziła: „Himalaizm to na pewno droga życiowa. [...]. To nie zmaganie się $\mathrm{z}$ rywalem, ale $\mathrm{z}$ naturą, $\mathrm{i}$ to $\mathrm{w}$ samotności. Wygrywa ten, kto zrozumie, że nie jest wszechmocny [...]. W górach nie zawsze droga kończy się na szczycie. [...]. Trzeba się cieszyć tym, że z gór schodzi się w całości i w zdrowiu. Takie podejście to oznaka pokory. [...] Myślę, że umiejętność ocenienia swoich sił i możliwości jest miarą dojrzałości, która jest niezbędna"23.

Takie rozumienie wspinaczki wysokogórskiej dominuje także w nauczaniu papieży XX wieku. Z tej perspektywy oceniają oni też jej wartość moralną. Papież Pius XII w około dwudziestu przemówieniach omawiał problemy ideowe i moralne sportu, wskazując na jego najgłębsze znaczenie. W tym kontekście porusza on też sens i wartość wspinaczki wysokogórskiej, jej pozytywne znaczenie dla kształtowania osobowości człowieka i dla jego wzrostu w cnotach. W jednym z przemówień podkreśla on: „Czymże jest sport, jeżeli nie jedną $z$ form formacji? To wychowanie pozostaje $w$ ścisłej relacji z moralnością [...]. Jakie jest więc na pierwszym miejscu zadanie i cel sportu, rozumianego w sposób zdrowy i chrześcijański, jeżeli nie pielęgnowanie godności i harmonii ludzkiego ciała, rozwijanie zdrowia, tężyzny, sprawności i łaski. Sport jest skutecznym antidotum na zniewieściałość i życie wygodne, budzi poczucie porządku i wychowuje do [...] panowania nad sobą, do pogardy dla niebezpieczeństwa bez przechwalania się i małoduszności. [...] Wynosi ponad samą siłę fizyczną i prowadzi do potęgi i wielkości moralnej" ${ }^{24}$.

W przemówieniu tym odwołuje się też do wspomnień Achillesa Rattiego, późniejszego papieża Piusa XI, który w swym kapłańskim życiu praktykował

\footnotetext{
${ }^{22}$ K. Pytlakowska, Piękna himalaistka.

${ }^{23}$ Kinga Baranowska - pierwsza dama polskiego himalaizmu? „Drytooling. com.pl”, http://drytooling.com.pl/baza/ludzie/719-kinga-baranowska (dostęp: 20.09.2018).

${ }^{24}$ PIO XII, Discorso agli sportivi italiani (20.05.1945), http://w2. vatican.va/content/piusxii/it/speeches/1945/documents/hf_p-xii_spe_19450525_sport.html (dostęp: 20.01.2019); por. także (m.in.) tenże Discorso ai partecipanti al «xxIx giro ciclistico d'Italia»(12.06.1946), http://w2.vatican.va/content/pius-xii/it/speeches/1946/documents/hf_p-xii_spe_19460626_girociclistico-italia.html (dostęp: 20.01.2019); Discorso ai partecipanti al congresso scientifico nazionale italiano dedicato alle attività ginnico-sportive (8.11.1952), http://w2.vatican.va/co ntent/pius-xii/it/speeches/1952/documents/hf_p-xii_spe_19521108_gran-cuore.html (dostęp: 20.01.2019); Discorso ai dirigenti e agli associati del centro sportivo italiano (9.10.1955), http://w2.vatican.va/content/pius-xii/it/speeches/1955/documents/hf_p-xii_spe_19551009_centrosportivo-italiano.html (dostęp: 22.01.2019).
} 
wspinaczkę wysokogórską i zdobył pięć szczytów zaliczanych do korony Alp, w tym Mont Blanc i Matterhorn. W opublikowanych wspomnieniach Achilles Ratti wskazuje na alpinizm jako źródło wielkiego doświadczenia wszechmocy i majestatu Boga. Dalej opisuje zmaganie się z samym sobą, kiedy po całodziennym wspinaniu się po stromej ścianie Monte Rossa w Alpach, spędził całą noc na wysokości 4600 m n.p.m., w ekstremalnym zimnie, stojąc na wąskim skalnym występie bez możliwości poruszania się i bez możliwości drzemki ${ }^{25}$.

Powyższe walory alpinizmu eksponuje również pap. Paweł VI. Stwierdza on między innymi: ,alpinizm, rozumiany nie jako lekkomyślne popisywanie się, ale jako zdobywanie coraz trudniejszych celów, panowanie nad sobą, może być wielką szkołą dojrzewania silnych osobowości; tutaj nabywa się postawy braterskiej, ducha służby, wzajemnej i wielkodusznej pomocy [...] odrzucania wygodnego i zniewieściałego życia. [...] Taka szkoła może i winna być ważną pomoca dla autentycznej formacji chrześcijańskiej [...]"26. W dalszej części przemówienia papież rozwija podstawowe wymiary alpinizmu, który staje się narzędziem rozwoju bogatego w cnoty człowieczeństwa przez doświadczenie swojej małości wobec potęgi Boga, pełnego dobroci, wielkiego, ale bliskiego człowiekowi ${ }^{27}$. Jan Paweł II także poświęcał wiele uwagi wartości sportu. Zasadniczo uczył o nich w kontekście dyscyplin klasycznych, a zwłaszcza futbolu.

\section{PODSUMOWANIE}

Większości dyscyplin sportowych towarzyszy określone ryzyko. Jeśli chodzi o sporty amatorskie jest ono minimalne i łatwe do uniknięcia. W przypadku dyscyplin zminimalizowanego ryzyka ich uprawianie tylko w wyjątkowych

\footnotetext{
25 Por. A. RatTI, Scritti alpinistici, Bertieri e Vanzetti, Milano 1923, s. 42-43.

${ }^{26}$ PAOLO VI, Discorso al consiglio centrale del club alpino italiano (29.01.1973), http:// w2.vatican.va/content/paul-vi/it/speeches/1973/ january/documents/hf_p-vi_spe_19730129_clubalpino.html (dostęp: 29.09.2018).

${ }^{27}$ Por. tamże; por. także Messaggio per i Giochi olimpici invernali a Grenoble (24.01. 1968), w: Insegnamenti di Paolo VI, t. 6, Tipografia Poliglotta Vaticana, Vaticano 1968, s. 5355; Messaggio agli atleti di tutte le nazioni per la XIX Olimpiade a Città del Messico (12.10. 1968), w: Insegnamenti di Paolo VI, t. 6, Tipografia Poliglotta Vaticana, Vaticano 1968, s. 519-521; Messaggio per i Giochi olimpici invernali al vescovo di Innsbruck (14.12.1976), w: Insegnamenti di Paolo VI, t. 14, Tipografia Poliglotta Vaticana, Vaticano 1977, s. 115; Messaggio per la XXI Olimpiade a Montreal (16.07.1976), w: Insegnamenti di Paolo VI, t. 14, Tipografia Poliglotta Vaticana, Vaticano 1977, s. 589-590.
} 
sytuacjach domaga się szczególnego postępowania asekuracyjnego. Konsekwentnie moralne uwarunkowania raczej nie tworzą tutaj poważnych barier. Wprost przeciwnie, ich uprawianie może być pożądane, kiedy stają się środkiem służącym zdrowiu fizycznemu i duchowemu człowieka oraz rozwijaniu pozytywnych relacji społecznych.

Inaczej przedstawia się sytuacja w przypadku sportów ekstremalnych i wielkiego ryzyka. Ich praktykowanie domaga się nie tylko spełnienia warunków bezpieczeństwa, ale także proporcjonalnych racji usprawiedliwiających podjęcie tego ryzyka. Do tych racji można zaliczyć poważne dobro osobiste lub społeczne. Jeszcze większe wymagania rodzi wspinaczka wysokogórska, zwłaszcza himalaizm. Jest on sportem wielkiego, jeżeli nie wprost najwyższego ryzyka, gdzie granica między etycznym i nieetycznym postępowaniem jest przeważnie bardzo subtelna. Praktykowania tego sportu nie są w stanie usprawiedliwić spłycone motywy, a więc chęć rywalizacji, przeżycia przygody, szukania wrażeń, zdobycia sławy czy prestiżu społecznego, jakkolwiek sport ten sam w sobie staje się przeważnie źródłem popularności i społecznego uznania $^{28}$. Nie wystarczą też psychofizyczne predyspozycje, odpowiednie przygotowanie, doświadczenie i wysokiej klasy sprzęt. Wymagania te stanowią warunek wstępny, nieodzowny w każdym wymagającym sporcie. Tylko wysokie moralne motywy i wartości są w stanie usprawiedliwić podjęcie towarzyszącego temu sportowi ryzyka. Może więc być on uznany za moralnie dobry, jeżeli w zasadniczym zamiarze, przynajmniej domyślnie, służy integralnemu rozwojowi człowieka. W ekstremalnych warunkach bowiem może on intensywnie rozwijać szlachetne postawy i moralne cnoty, ćwiczyć się w panowaniu nad sobą i przezwyciężać swoje słabości. Jednocześnie już na wstępie muszą zostać podjęte środki bezpieczeństwa, wykluczone uświadomione przeciwskazania, a zagrożenia zawężone do przypadkowych, nadzwyczajnych i trudnych do przewidzenia sytuacji ${ }^{29}$.

Towarzyszące temu sportowi poważne ryzyko nie może być lekceważone. Jak zasugerowała Kinga Baranowska, w tej dziedzinie człowiekowi nie wolno przekraczać granic swoich możliwości. Obowiązek troski o życie i zdrowie domaga się odpowiedzialnego podejmowania decyzji i rezygnacji z bliskiego

\footnotetext{
${ }^{28}$ Więcej na ten temat por. Z. DZIUBIŃSKI, Geneza prestiżu sportu i sport jako źródto prestiżu, w: Kultura fizyczna a prestiz społeczny, red. Z. Dziubiński, M. Lenartowicz, Akademia Wychowania Fizycznego i Salezjańska Organizacja Sportowa, Warszawa 2018, s. 15-35; J. LIPIEC, Prestiz sportu - prestiz sportowca, w: tamże, s. 57-70.

${ }^{29}$ Por. L. CicCONE, «Non uccidere». Questioni di morale della vita fisica, Edizioni Ares, Milano 1984, s. 411-412, 416-419.
} 
już sukcesu. Wtedy właśnie himalaizm (także wspinaczka wysokogórska) jest w stanie spełnić sobie właściwą rolę: człowiek potwierdza swoją wielkość przez pokorne uznanie swoich ograniczonych możliwości. Prawdziwym sukcesem, nadającym sens wysokogórskiej wspinaczce, jest szczęśliwy powrót do gwarantującego bezpieczeństwo obozu czy schroniska. Konsekwentnie z moralnego punktu widzenia akceptacja ekstremalnego ryzyka może być tylko wtedy zrozumiała, gdy zagrażające niebezpieczeństwo jest następstwem przypadkowych zdarzeń, niezależnych od himalaisty.

\section{BIBLIOGRAFIA}

JAN PAWEŁ II, Encyklika Evangelium vitae, Rzym 1995.

PIO XII, Discorso agli sportivi italiani (20.05.1945), http://w2.vatican.va/co ntent/pius-xii/it/ speeches/1945/documents/hf_p-xii_spe_19450525_sport.html (dostęp: 20.01.2019).

PIO XII, Discorso ai partecipanti al «xxIx giro ciclistico d'Italia» (12.06.1946), http://w2.vati can.va/content/pius-xii/it/speeches/1946/documents/hf_p-xii_spe_19460626_giro-ciclisticoitalia.html (dostęp: 20.01.2019).

PIO XII, Discorso ai partecipanti al congresso scientifico nazionale italiano dedicato alle attività ginnico-sportive (8.11.1952), http://w2.vatican.va/content/pius-xii/it/speeches/1952/do cuments/hf_p-xii_spe_19521108_gran-cuore.html (dostęp: 20.01.2019).

PIO XII, Discorso ai dirigenti e agli associati del centro sportivo italiano (9.10.1955), http:// w2.vatican.va/content/pius-xii/it/speeches/1955/documents/h f_p-xii_spe_19551009_centrosportivo-italiano.html (dostęp: 22.01.2019).

PAOLO VI, Messaggio per i Giochi olimpici invernali a Grenoble (24.01.1968), w: Insegnamenti di Paolo VI, t. 6, Tipografia Poliglotta Vaticana, Vaticano 1968, s. 53-55.

PAOLO VI, Messaggio agli atleti di tutte le nazioni per la XIX Olimpiade a Città del Messico (12.10.1968), w: Insegnamenti di Paolo VI, t. 6, Tipografia Poliglotta Vaticana, Vaticano 1968, s. 519-521.

PAUL VI, Discours aux représentants des forces armées (du Conseil International du Sport Militaire) (29.11.1969), http://w2.vatican.va/content/paul-vi/fr/ speeches/1969/november/docu ments/hf_p-vi_spe_19691129_forze-armate.html (dostęp: 20.01.2019).

PAOLO VI, Discorso al consiglio centrale del club alpino italiano (29.01.1973), http://w2.vati can.va/content/paul-vi/it/speeches/1973/january/documents/hf_p-vi_spe_19730129_club-alpi no.html (dostęp: 29.09.2018).

PAOLO VI, Messaggio per la XXI Olimpiade a Montreal (16.07.1976), w: Insegnamenti di Paolo VI, t. 14, Tipografia Poliglotta Vaticana, Vaticano 1977, s. 589-590.

PAOLO VI, Messaggio per i Giochi olimpici invernali al vescovo di Innsbruck (14.12.1976), w: Insegnamenti di Paolo VI, t. 14, Tipografia Poliglotta Vaticana, Vaticano 1977, s. 115.

SOBÓR WATYKAŃSKI II, Konstytucja duszpasterska o Kościele w świecie współczesnym Gaudium et spes, Rzym 1965.

SoBÓR WATYKAŃSKI II, Deklaracja o wychowaniu chrześcijańskim Gravissimum educationis, Rzym 1965. 
AlLIANZ, Ogólne warunki bezpieczeństwa w podróży Globtroter Direct, https://www.allian zdirect.pl/dokumenty-do-pobrania/owu-globtroter-20101029_literxwka_str_3_pkt_56.pdf (dostęp: 18.09.2018).

CicCone L., «Non uccidere». Questioni di morale della vita fisica, Edizioni Ares, Milano 1984.

DZIUBIŃSKI Z., Geneza prestiżu sportu i sport jako źródło prestiżu, w: Kultura fizyczna a prestiż społeczny, red. Z. Dziubiński, M. Lenartowicz, Akademia Wychowania Fizycznego i Salezjańska Organizacja Sportowa, Warszawa 2018, s. 15-35.

ERGo HeStIA, Słownik terminów ubezpieczeniowych, https://www.ergohestia.pl/centrum-wiedzy/slownik-terminow-ubezpieczeniowych/ (dostęp 20.09.2018).

Etyka we współczesnym alpinizmie - Szczyt Gliwicki 1987 (cz. 1), „Wspinanie.pl”, https:// ws pinanie.pl/2013/10/etyka-we-wspolczesnym-alpinizmie-szczyt-gliwicki-1987-cz-1/ (dostęp: 20.09.2018).

Europäische Reiseversicherung AG, Ogólne Warunki Ubezpieczenia Beztroskie Podróże $\mathrm{Nr}$ 10.10.009, https://www.erv.pl/files/193/148/51/1010007a4.pdf (dostęp: 20.09.2018).

GÜNTHÖR A., Chiamata e risposta. Una nuova teologia morale, t. 1: Morale generale, Edizioni Paoline, Roma $1979^{3}$.

Kinga Baranowska - pierwsza dama polskiego himalaizmu? „Drytooling.com.pl”, http://drytoo ling.com.pl/baza/ludzie/719-kinga-baranowska (dostęp: 20.09.2018).

KuKUCZKa J., MALANOwsKi T., Na szczytach świata, Fundacja Wielki Człowiek, Katowice $2013^{3}$. LIPIEC J., Prestiż sportu - prestiż sportowca, w: Kultura fizyczna a prestiż społeczny, red. Z. Dziubiński, M. Lenartowicz, Akademia Wychowania Fizycznego i Salezjańska Organizacja Sportowa, Warszawa 2018, s. 57-70.

MAJ J., Pojęcie sportu wyczynowego w prawie Unii Europejskiej, „Prawo Sportowe.pl”, https:// prawosportowe.pl/pojecie-sportu-wyczynowego-w-prawie-unii-europejskiej.html - (dostęp: 24.09.2018).

Międzynarodowa Rada Sportu Wojskowego ma 70 lat, „Polska Zbrojna”, http://www.polskazbrojna.pl/home/articleshow/26001?t=Miedzynarodowa-Rada-Sportu-Wojskowego-ma-70-lat (dostęp: 20.01.2019).

Ministerstwo Obrony Narodowej, Gala sportu wojskowego, http://archiwalny.mon.gov.pl/pl/ar tykul/2792 (dostęp: 20.01.2019).

Montanari B., Sport, w: Nuovo dizionario di teologia morale, red. F. Compagnoni, G. Piana, S. Privitera, Edizioni Paoline, Milano 1990, s. 1279-1289.

Perico G., Sport, w: Dizionario enciclopedico di teologia morale, red. L. Rossi, A. Valsecchi, Edizioni Paoline, Roma 1976, s. 1034-1043.

PeschKe K.-H., Christliche Ethik. Grundlegungen der Moraltheologie, Paulinus Verlag, Trier 1997.

Pytlakowska K., Piękna himalaistka Kinga Baranowska zdradza swoje tajemnice [wywiad], „Polki.pl”, https://polki.pl/zycie-gwiazd/newsy,himalaistka-kinga-baranowska-w-vivie-wywiad-z-kinga-baranowska-w-vivie,10032989, artykul. html (dostęp: 20.09.2018).

RATTI A., Scritti alpinistici, Bertieri e Vanzetti, Milano 1923.

SCHOCKENHOFF E., Ethik des Lebens. Grundlagen und neue Herausforderungen, Verlag Herder, Freiburg im Br. 2013².

SZYMCZYK R., MedEverest Mountain Expedition Medicine, http://medeverest. com/o-firmie.html (dostęp: 27.09.2018).

SZYMCZYK R., MedEverest Mountain Expedition Medicine: Aklimatyzacja, http://medeve rest.com/aklimatyzacja.html (dostęp: 27.09.2018).

WARTA, Ogólne Warunki Ubezpieczenia Warta Travel Plus, https://www.warta. pl/documents /10157/916069/Warta_Travel_plus_OWU.pdf (dostęp: 18.09. 2018). 
ETYCZNY WYMIAR RYZYKA W SPORCIE

S t r e s z c z e n i e

Autor omawia problem etycznego wymiaru ryzyka, które towarzyszy większości dyscyplin sportowych. Ich uprawianie tylko wyjątkowo stwarza poważne problemy moralne. Z reguły stają się one środkiem służącym zdrowiu fizycznemu i duchowemu człowieka. Praktykowanie sportów ekstremalnych i sportów wysokiego ryzyka może służyć rozwojowi duchowemu i moralnemu człowieka. Musi ono jednak spełnić warunki ogólnego i specjalistycznego bezpieczeństwa oraz musi mu towarzyszyć gotowość rezygnacji z dalszej wspinaczki, kiedy realne zagrożenie przekracza roztropnie ocenione możliwości himalaisty.

Słowa kluczowe: alpinizm; himalaizm; ryzyko; sport; teologia moralna. 